九州大学学術情報リポジトリ

Kyushu University Institutional Repository

$\mathrm{Rb}-\mathrm{Sr}$ Whole Rock Ages of the Granites of Minami-osumi and Amami-oshima, Southwest Japan

Yanagi, Takeru

Faculty of Science, Kyushu University

Yamaguchi, Masaru

Faculty of Science, Kyushu University

Nozawa, Tamotsu

Geological Survey of Japan

https://doi.org/10.5109/1544091

出版情報：九州大學理學部紀要：Series D, Geology. 21 (1)，pp. 163-175，1971-10-25. Faculty of Science, Kyushu University バージョン：

権利関係 : 
Mem. Fac. Sci., Kyushu Univ., Ser. D, Geology, Vol. XXI, No. 1,

pp. 163-175, text-figs. 1-6, table 1, October, 25, 1971

\title{
Rb-Sr Whole Rock Ages of the Granites of Minami-osumi and Amami-oshima, Southwest Japan
}

By

\author{
Takeru YANAgI, Masaru YamaguchI and Tamotsu NozAwA
}

\begin{abstract}
The Minami-osumi granite and the granites from Amami-oshima were analyzed for strontium and rubidium by the isotope dilution method. The ages calculated from the slopes on the isochron diagram are $(64 \pm 11) \mathrm{m} . \mathrm{y}$. with an initial strontium $87 / 86$ ratio of $0.7071 \pm 0.0002$ for the Minami-osumi granite and $(105 \pm 27)$ m.y. with an initial strontium $87 / 86$ ratio of $0.7065 \pm 0.0002$ for the granites from Amami-oshima. An order of the differences between the whole rock ages and the K-Ar ages on biotite is about 50 m.y. These whole rocks ages represent the oldest limit of the time of differentiation of these granitic magmas. Relatively high initial strontium ratios of these granites along with other lines of evidence are assumed to suggest the the existence of older rocks in the source region of these granites.
\end{abstract}

\section{Introduction}

In order to know the meaning of the difference between a Rb-Sr whole rock age and a $\mathrm{K}$-Ar biotite age of a granite and to correlate these ages to stratigraphical records around the granite, we have undertaken a study of young granite bodies.

The Minami-osumi granite in the south of the Osumi Peninsula, southern Kyushu Island, is one of the largest among the younger granites in the Outer Zone of Southwest Japan. It is well exposed with little later disturbance. The high rubidium strontium ratios have already been reported from this granite by Kawano et al. (1966). Miller et al. (1962), and Kawano and Ueda (1966) have reported $\mathrm{K}-\mathrm{Ar}$ ages on biotite from this body. These ages vary in a wide range from 14 m.y. to 22 m.y. which is wider than those of other younger granites in the Outer Zone of Southwest Japan.

SHUTo (1963) has noted from the study of the Nichinan group that these radiometric ages are somewhat younger than the time of intrusion of the granite. In addition, a possibility of presence of two bodies in the granite with different ages of intrusion has been pointed out by MrYAHISA et al. (1953), Momor (1958), and NozAWA and OTA (1967). OBA (1960) has proposed three rock types of the granite with different rock facies. However, no conclusive evidence has been found in the granite to support the presence of two kinds of intrusion. While the possibility should be proved in some way later, this

Manuscript received May 31,1971 
variation of ages does not necessarily obstruct the present study because an error of the whole rock age may be greater.

Granites from Amami-oshima were also selected for comparison. K-Ar ages of these granites reported by SHIBATA and NozAWA (1966) are older than those of the Minami-osumi granite.

We wish to express our thanks to Professors S. TANeda and T. Matsumoto who have given us support to this study and critically read the manuscript. We owe much to Dr. H. HATTORI of the Geological Survey of Japan for the preliminary determination of rubidium and strontium concentrations by the X-ray spectrometry and to Miss R. HAMAмото for her help of operation of the mass spectrometer during the course of this study. This study has been financially supported by a Grant-in-Aid for Scientific Research from he Ministry of Education.

\section{Geological Setting}

In the Outer Zone of Southwest Japan, late Mesozoic to older Tertiary geosynclinal pile of clastic sedimentary rocks, called the Shimantogawa group or complex, are exposed to the south of the Chichibu orogenic belt, extending

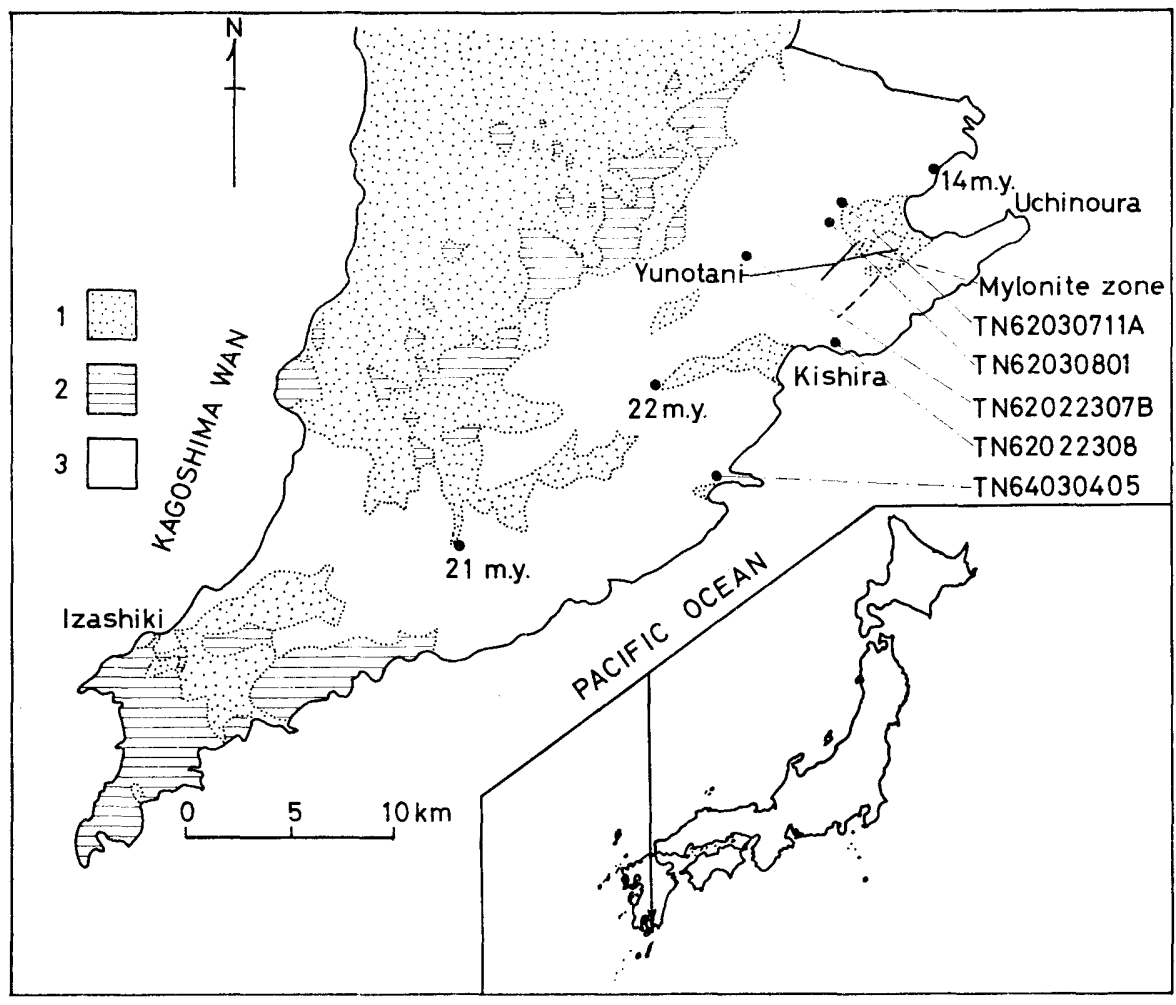

Fig. 1. Geological map of the southern part of the Osumi Peninsula and sample localities of the Minami-osumi granite. 1: Quaternary sediments, 2: Shimantogawa sedimentary complex, 3: Minami-osumi granite. 
from the southern part of central Japan through Shikoku, Kyushu to the Ryukyu Islands. In these sedimentary rocks several basaltic lavas with the pillow structure and some acid volcanic ashes are intercalated, as reported by SHUTO (1963), HASHimoto (1962), etc. Although fossils occur sparsely, the evidence for biostratigraphical correlation has recently been increased (e.g. see MATSUMOTO et al., 1969, as well as SHuto, 1963). The rocks of the Shimantogawa complex were intensely folded and faulted at about the middle of the Cenozoic age and some of them were slightly metamorphosed (SHUTO, 1963; HASHIMoTo, 1962; IMAI et al., 1971). Intrusions of small stocks and dykes of granitic and volcanic rocks took place in folded sedimentary rocks of the Shimantogawa before the deposition of the Middle Miocene to Lower Pliocene Miyazaki group. The distribution of these rocks has been shown by NozAwA (1968) along with K-Ar mineral ages of the granitic rocks. The Minamiosumi granite is one of these granite bodies exposed in the Osumi Peninsula, southern Kyushu.

Hashimoto and MiYahisa (1959) and Hashimoto (1961) have studied the volcanic complex and sedimentary formations in southern Kyushu and have reported that the volcanic complex was formed immediately after the deposition of the Iorigawa conglomerate which lies unconformably on the Upper Oligocene to Lower Miocene Kadogawa formation and have concluded that the volcanic activities occurred in the Middle Miocene age. MIYAHISA et al. (1953) has correlated the Minami-osumi granite to other granitic rocks of southern Kyushu by comparing the colour of assembled zircon from these igneous rocks.

Radiometric age determination was done by MILLER et al. (1962), KAwaNo

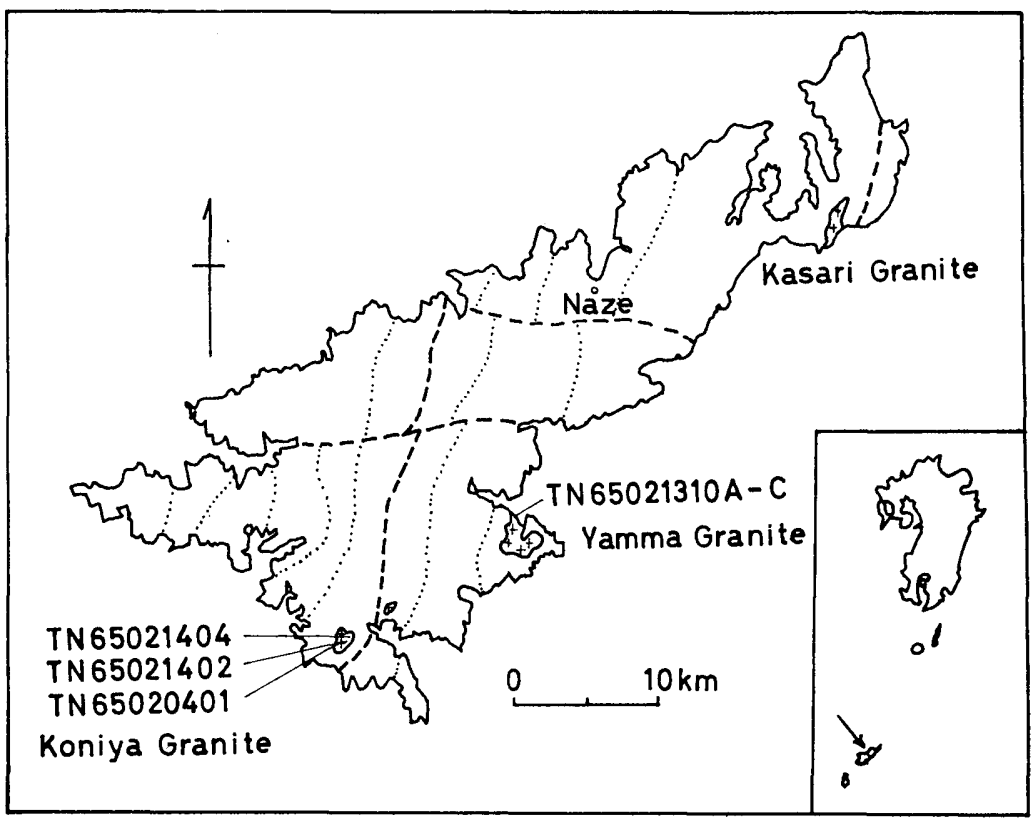

Fig. 2. Geological outline map of Amami-oshima with sample localities of the granites. 
and Ueda (1966), Shibata and NozAwa (1968a-f), and HAYASE and Ishizaka (1968) for the young granites in this region. The ages ranging from $11 \mathrm{~m} . \mathrm{y}$. to 35 m.y. are well in agreement with the conclusion of HAsHimoto et al. (1959) and MIYAhisA (1958).

Older ages of $49-56$ m.y. determined on the granites from the Ryukyu Islands were reported by SHIBATA and NozAWA (1966). NozAWA (1968) has summarized radiometric ages on minerals of granitic rocks in the Outer Zone of Southwest Japan and its extension and found three peaks of 14 m.y., 21 m.y. and 55 m.y.

Before this, KoNISHI (1965) has attempted geotectonic zoning on the Ryukyu Islands and has reported the geohistorical similarity between the Pre-miocene basement complex of the Ryukyu Islands and the Outer Zone of Southwest Japan. $\mathrm{He}$ has also suggested that the granites in Amami-oshima may be mostly of Miocene age but that some older granites could possibly exist in this island.

\section{Sample Collection and Experimental Procedure.}

Rock specimens of the Minami-osumi granite and the granites from Amamioshima were collected by NozAWA and OTA, and NozAWA and SHIBATA respectively. Detailed descriptions of the samples of the Minami-osumi granite were given by NoZAWA and OTA (1967) with a precise geological map of the Uchinoura district. K-Ar ages on biotite of the samples from Amami-oshima, which were used in this experiment, have already been reported by SHIBATA and NozawA (1966).

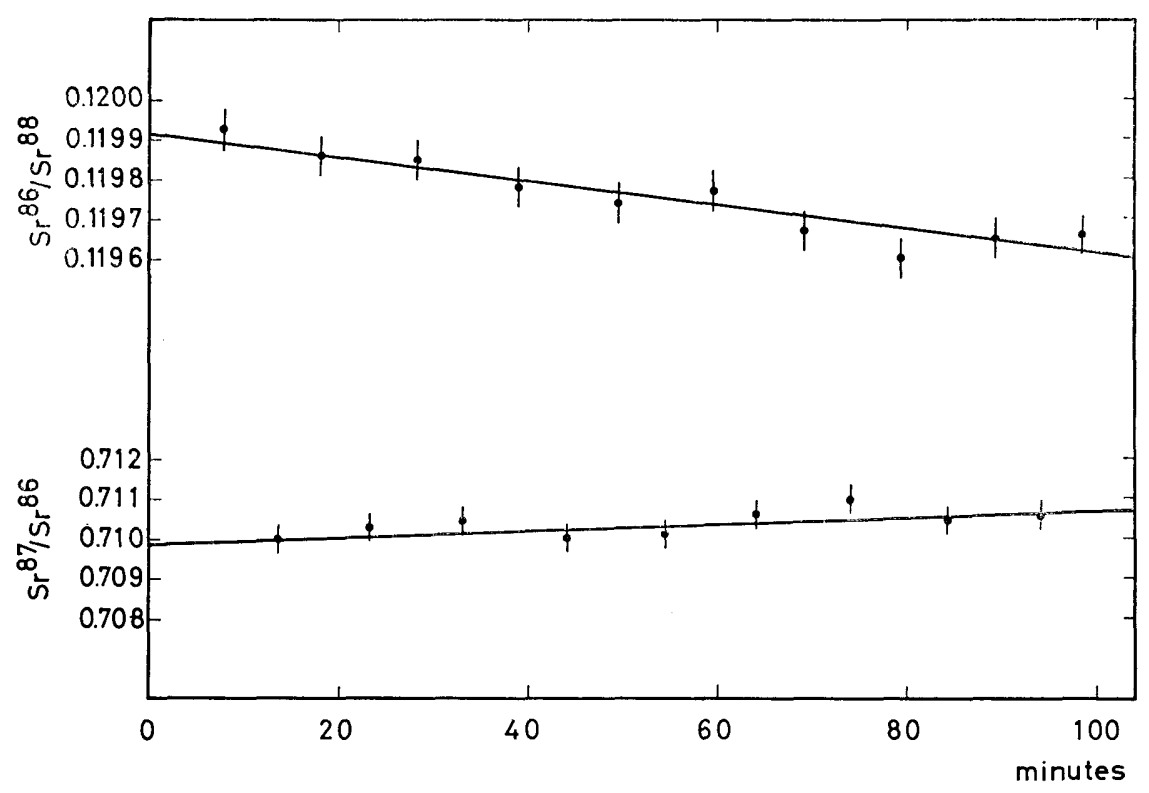

Fig. 3. Variations of strontium $86 / 88$ ratios and strontium $87 / 86$ ratios of TN $65021310 \mathrm{C}$ in the mass spectrometry. A normalized strontium 87/86 ratio is $0.71147 \pm 0.00020$. 
In the present study samples were in most cases prepared from $1-2 \mathrm{~kg}$ of rocks, and their rubidium and strontium concentrations were preliminarily determined with the X-ray fluorescence method. Then the samples were analyzed for strontium isotope composition, rubidium and strontium concentrations at Kyushu University with a $20 \mathrm{~cm}$ radius mass spectrometer using analytical techniques described elsewhere (YAmaguchi et al., 1969; YANAGi et al., 1970). Ages were calculated using a decay constan of $1.39 \times 10^{-11}$ year $^{-1}$.

\section{Strontium Isotope Ratio Measurement}

Since the ages of the granites are young, and the variation of rubidium strontium ratios in these granites is small, high precision of measurement of strontium $87 / 86$ ratios is needed for the whole rock age measurement.

About $8 \mu \mathrm{g}$ of unspiked strontium nitrate in solution were loaded carefully not to spread over the center of an ionization filament of tantalium. Then the filament was heated at red glow for 10 to 20 seconds. The single surface ionization technique was employed to simplify the variation of strontium ratios with time by the discrimination in the mass specrometer. The filament current was gradually increased and then potassium and rubidium in the sample loaded on it were eliminated. The filament current was kept constant for 4 to 5 hours when the strontium peaks were detected on a recorder. The strontium ion current was gradually increased and reached to $1 \times 10^{-11} \mathrm{~A}$. Strontium ratios were measured at the strontium 88 ion current below $3 \mathrm{~V}\left(3 \times 10^{-11} \mathrm{~A}\right)$ to avoid voltage dependent variation of a imput resistance of a solid state D.C. amplifier. No correction of

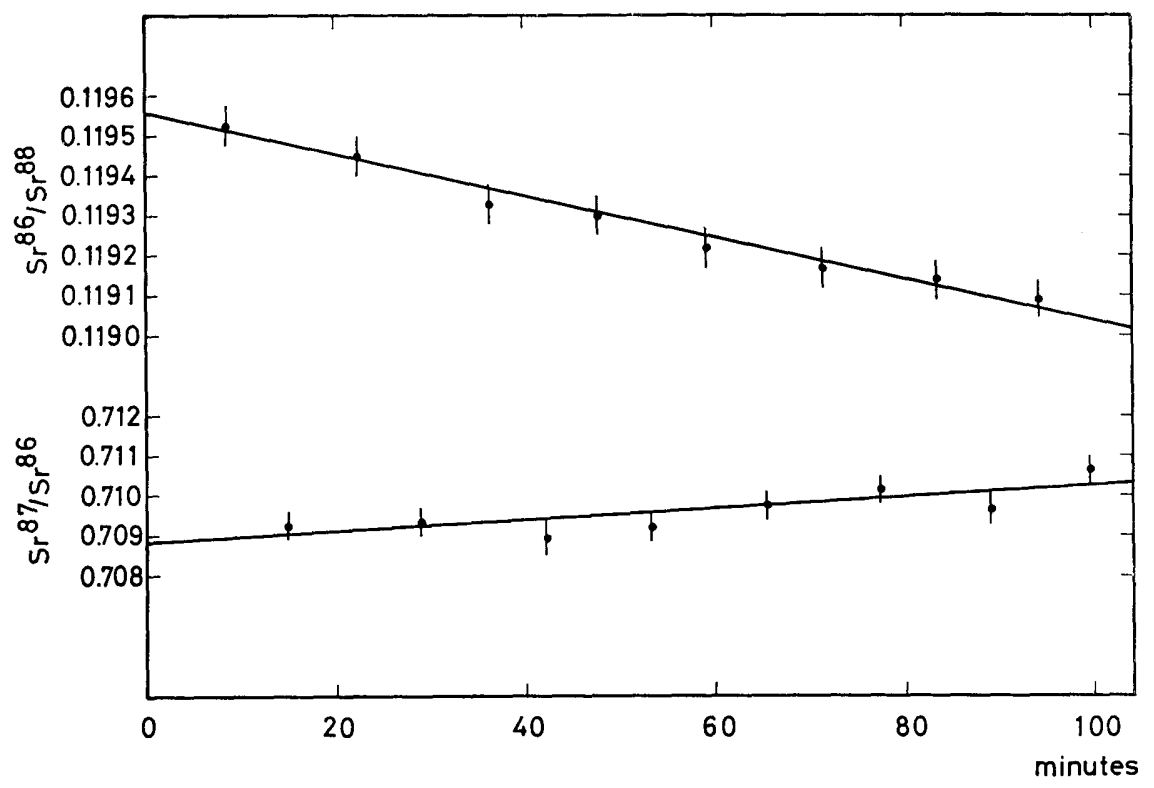

Fig. 4. Variations of strontium $86 / 88$ ratios and strontium $87 / 86$ ratios of TN 62030801 in the mass spectrometry. A normalized strontium $87 / 86$ ratio is $0.70923 \pm 0.00026$. 
the change of the resistance for strontium ratios was made. It has been found that strontium isotope ratios determined by a single filament technique vary with time elapsed (YAMAGUCHI et al., 1969). Therefore about 300 to 500 peak sets of strontium 86 and 88 and of strontium 87 and 86 were taken at constant temperature of the filament and the change of the ratios with time elapsed from the beginning of measurement was determined. Two representative diagrams are shown in Figs. 3 and 4 . Each point in these diagrams represents a mean value of about 25 isotope ratios and a mean time passed from the beginning of measurement. It is found from these diagrams that the strontium isotope ratios change almost linearly with time in a small range of variation of the strontium ratios. Normalization of strontium $87 / 86$ ratio to strontium $86 / 88$ ratio of 0.1194 was made by interpolating or extrapolating these time dependent discrimination lines. Discrimination factors were examined by plotting these isotope ratios of Figs. 3 and 4 on a diagram of logalism of the isotope ratios following OzARD and RUsSell (1970). Slopes of the discrimination lines were about 0.48 , slightly lower than the theoretical value of 0.5 .

An error ( 2 standard deviations) of a normalized strontium $87 / 86$ ratio is

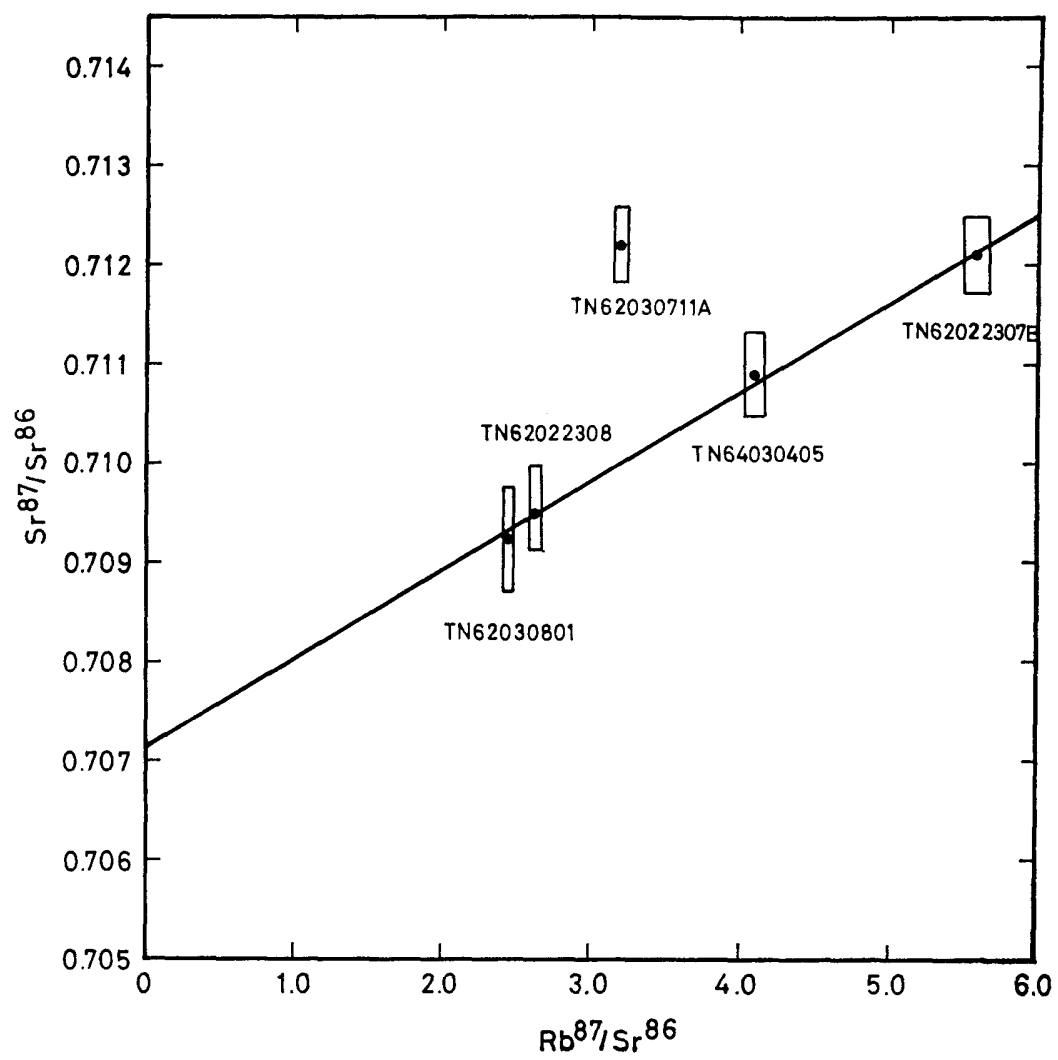

Fig. 5. Rb-Sr whole rock isochron diagram for the Minami-osumi granite. The slope gives an age of $(64 \pm 11) \mathrm{m}$. $\mathrm{y}$. with an initial strontium $87 / 86$ ratio of $0.7071 \pm 0.0002$. 
Table 1. Rb-Sr analytical data

\begin{tabular}{llrrrrrr}
\hline Sample No. & Rock & $\begin{array}{c}\mathrm{Rb}^{87} \\
\mu \mathrm{mol} / \mathrm{g}\end{array}$ & $\begin{array}{c}\mathrm{Rb} \\
\mathrm{ppm}\end{array}$ & $\begin{array}{c}\mathrm{Sr} \\
\mu \mathrm{mol} / \mathrm{g}\end{array}$ & $\begin{array}{c}\mathrm{Sp} \\
\mathrm{ppm}\end{array}$ & $\mathrm{Rb}^{87} / \mathrm{Sr}^{86}$ & $\mathrm{Sr}^{87} / \mathrm{Sr}^{86}$ \\
\hline $\begin{array}{l}\text { The Minami-osumi granite } \\
\text { TN 62030801 }\end{array}$ & Granodiorite & 0.509 & 156.2 & 0.2078 & 184.6 & 2.450 & $0.70923 \pm 0.00038$ \\
TN 62022308 & Adamellite & 0.546 & 167.5 & 0.2076 & 185.0 & 2.629 & $0.70947 \pm 0.00038$ \\
TN 62022308B & $\begin{array}{l}\text { Porphyritic } \\
\text { granite }\end{array}$ & 0.599 & 183.9 & 0.1074 & 95.5 & 5.580 & $0.71207 \pm 0.00038$ \\
TN 64030405 & Granodiorite & 0.619 & 189.9 & 0.1509 & 134.2 & 4.099 & $0.71087 \pm 0.00042$ \\
TN 62030711A A Granodiorite & 0.584 & 179.3 & 0.1819 & 161.7 & 3.211 & $0.71217 \pm 0.00038$ \\
& & & & & & & \\
Granites from Amami-oshima & & & & & & \\
TN 65021310A & Tonalite & 0.446 & 136.9 & 0.1655 & 147.1 & 2.695 & $0.71034 \pm 0.00038$ \\
TN 65021310B & Tonalite & 0.422 & 129.3 & 0.1404 & 124.8 & 3.002 & $0.71087 \pm 0.00044$ \\
TN 65021310C Quartz diorite & 0.468 & 143.5 & 0.1368 & 121.2 & 3.417 & $0.71147 \pm 0.00038$ \\
TN 65021402 & Granodiorite & 0.375 & 115.0 & 0.1517 & 134.8 & 2.471 & $0.71124 \pm 0.00038$ \\
TN 65020401 & Granodiorite & 0.406 & 124.7 & 0.1578 & 140.1 & 2.575 & $0.71008 \pm 0.00053$ \\
TN 65021404 & Tonalite & 0.339 & 104.1 & 0.1634 & 145.2 & 2.077 & $0.70956 \pm 0.00038$ \\
\hline
\end{tabular}

0.00038. Errors below 0.00038 were magnified to this level and errors over 0.00038 were shown in Table 1 and used for calculation of an error of an age.

\section{Experimental Results}

Concentrations of rubidium and strontium and strontium isotope ratios are shown in Table 1. Strontium $87 / 86$ ratios and rubidium strontium ratios of the Minami-osumi granite and the granites from Amami-oshima are plotted on isochron diagrams of Figs. 5 and 6 respectively.

Data of the Minami-osumi granite are well fitted to a least squares line calculated after the method of BRooks et al. (1968), except for a case of TN $62030711 \mathrm{~A}$ which includes biotite schist fragments in the sample and has significantly high strontium $87 / 86$ ratio which is plotted over the isochron. The isochron gives an age of $(6.4 \pm 1.1) \times 10^{7}$ years with an initial strontium $87 / 86$ ratio of $0.7071 \pm 0.0002$. The variation of rubidium strontium ratios of the granites from Amami-oshima is restricted and therefore, an age calculated has lower precision than that of the Minami-osumi granite. The data of the granites from Amami-oshima are also well fitted to an isochron, except for a case of TN 65021402. This sample has significantly high strontium $87 / 86$ ratio which is plotted over the isochron which is calculated for other five points of data. However the sample has no preexisting rock fragment and is collected from nearly the center of the granite body. Therefore one cannot find any reason responsible for a high strontium $87 / 86$ ratio but for its heterogeneous appearance. This isochron gives an age of $(1.05 \pm 0.27) \times 10^{8}$ years with an initial strontium $87 / 86$ ratio of $0.7065 \pm 0.0002$.

\section{Discussion}

The Minami-osumi granite is intruded into a sedimentary formation at the southern end of the Osumi Peninsula, which has been studied biostratigraphically 


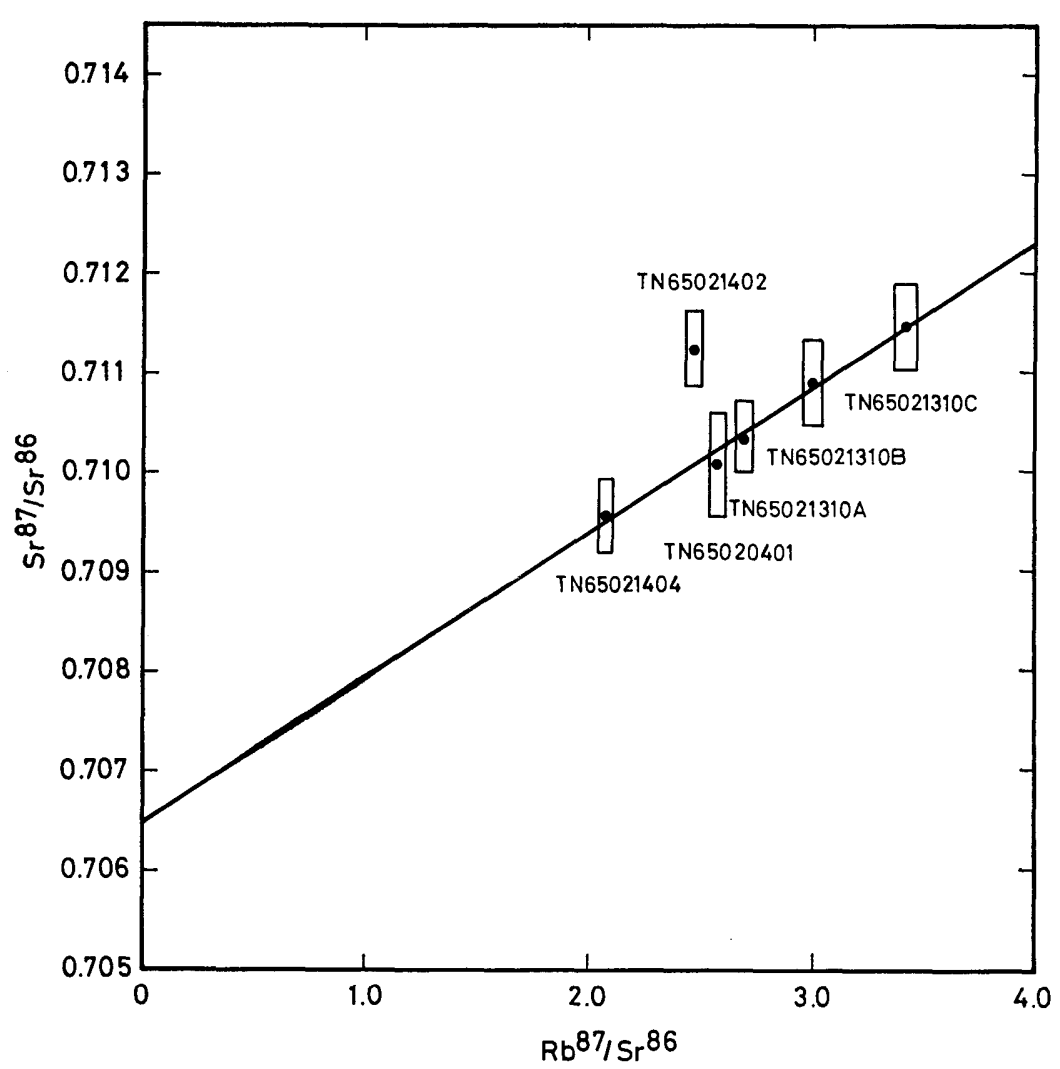

Fig. 6. Rb-Sr whole rock isochron diagram for the granites from Amamioshima, Ryukyu Islands. The slope gives an age of $(105 \pm 27) \mathrm{m} . \mathrm{y}$. with an initial strontium $87 / 86$ ratio of $0.7065 \pm 0.0002$.

by KuWANo (1960), with a conclusion of geological age younger than Lower Paleocene and older than Upper Eocene. This age is the lower limit of this granite intrusion. Stratigraphical evidence for the upper limit of the intrusion is not available around the granite.

The source of the granite fragments reported by SHUTo (1963) from the Lower Oligocene to Lower Miocene Nichinan group, occurring about $50 \mathrm{~km}$ apart to the northeast from this granite, could possibly be in the Minami-osumi granite. The Nichinan group was folded and faulted before the deposition of the Middle Miocene to Lower Pliocene Miyazaki group.

The Osuzu volcanic complex formed immediately after the deposition of the Iorigawa conglomerate which lies uncomformably on the Kadogawa formation of Upper Oligocene to Lower Miocene are covered by the Miyazaki group. This volcanic activities were followed by intrusions of granite dykes to the west of this volcanic complex. These granite dykes and the Osuzu volcanic complex have been correlated to the Minami-osumi granite and also to other granites in the Outer Zone of Southwest Japan. This result of correlation of granites has been proved to be correct with K-Ar radiometric dating on micas from the granites. It is also found, however, that the ages of the Minami-osumi granite range from 
14 m.y. to 22 m.y. and are significantly older than those of other granites of the Outer Zone of Southwest Japan.

If the granite fragments in the Nichinan group are assumed to be of the Minami-osumi granite, the age of intrusion of this granite would be in or before the Oligocene time. But some disagreement would exist between this assumption and the result of radiometic dating, oldest of which is 22 m.y. This disagreement should be explained in some way. The most intuitive explanation is that the granite was not cooled enough to retain radiometric argon in biotite while it was eroded at the surface of its top and deposited in the Nichinan group, or K-Ar ages were rejuvenated by later geological events.

The whole rock age can easily explain the occurrence of the granite fragment in the Nichinan group if the age is assumed to be the time of intrusion. Since the whole rock isochron age of $(64 \pm 11)$ m.y. and the age (younger than Lower Paleocene and older than Upper Eocene) of deposition of the sedimentary formatıon which is intruded by this granite are close to each other the whole rock age could be considered to be the time of intrusion.

One of tecconic teatures of the granite is the presence oi the mylonite zone in the granite reported by NozAWA and OTA (1967). 'They also reported that at the southern part of the mylonite zone, aplitic rocks are abundant, of which some are mylonitized and other are not, and concluded that the mylonitization occurred at the later stage of soliditication of the granite. 'Inerefore the time of the intrusion is not largely apart from the time of the iormation of the mylonite zone. But no eviaence is avallable to support that the mylonite zone was formed at the time of folding and faulting of the Nichinan group. K-Ar ages near the mylonite zone, however, could have been rejuvenated to some degree by the formation of the mylonite zone.

Snould the presence of two kinds of intrusion in the granite (MIYAHISA et al., 1953; Nomor, 1958; NozAWA et al., 196' 7 ) be admitted and the boundary of the two be assumed at the mylonite zone, the younger intrusion of a granite would have occurred in some time around 14 m.y. and the other would have been rejuvenated by the younger. Therefore the intrusion of older granite would have occurred in some time before $22 \mathrm{~m} . \mathrm{y}$.

Four small stocks of granite are exposed in Amami-oshima. Three of them are called Kasari, Yamma and Koniya granite respectively. SHIBATA and NozawA (1966) have shown that these three granite stocks are the contemporaneous intrusions by the K-Ar age measurement. 'The ages are 49 m.y. for the Kasari, 55 m.y. for the Yamma and 56,54 m.y. for the Koniya. Samples for the whole rocks age measurement of the present study were collected from the Yamma and the Koniya granite stocks (Fig. 2).

Only one Anmonite fossil, which indicates Upper Cretaceous age (probably Turonian), was found from the eastern part of this island (MATSumoto et al., 1966), where the Ogachi formation (HATAE et al., 1955) is exposed. This formation is intruded by the Yamma granite stock. Here again the whole rock age exceeds the age of the sedimentary formation which is intruded by the granite.

The whole rock age, along with $\mathrm{K}-\mathrm{Ar}$ ages, of the granites from Amami- 
oshima is distinctly older than that of the Minami-osumi granite. There arises a question whether or not Amami-oshima is situated on the direct extension of the plutonism of the Outer Zone of Southwest Japan.

The whole rock age of the Minami-osumi granite is meaningfully different from those determined on biotite with the K-Ar method. The discrepancy between the Rb-Sr whole rock age and the K-Ar biotite ages was found in each case of the Minami-osumi grantie and the granites from Amami-oshima. The order of the difference between them is almost the same. A similar order of the difference was found in granites from the Pennine Nappes, Southern Switzerland (JÄGER et al., 1967) and igneous rocks in the Roskrunge Mountains, Arizona (GoRAI, 1970). Recently one of us (T.Y.) has studied on a Cretaceous granite in north Kyushu and found the same difference between a $\mathrm{Rb}-\mathrm{Sr}$ whole rock age and $\mathrm{Rb}-\mathrm{Sr}$ biotite ages. Therefore the difference of about 50 m.y. between the whole rock age and the age determined on biocite seems to be worthwnile to be noted.

With respect to whole rock age dating there are some problems to be solved before a conclusion is drawn that the age represents a time of differentiation of a granitic magma. As stated by NAYLER et al. (1970), the fit of the data to a straight line is necessary but not sufticient evidence for concluding that the samples are of the same age and had identical initial strontium $8 / / 86$ ratios. in some cases the ditterentiation may have proceeded so graqually as to assimilate preexisting rocks around the granıtic magma without complete mixing. Therefore an arrangement of data well fitting to a straight line does not always mean that the granila nayma was so nomogeneous ror suronuum isocope composicion as not to give rise 20 any primary isochron. in particular, contribution of the primary isochron may ve very signincant to the tume oi the difierentiation when a young granicic magma assimilated much older preexisting granitic rocks.

BELL and POWELL (1969) reported high positive correlation between strontium 87/86 ratios and rubidium strontium ratios of potassium-rich lavas of Pliocene and younger ages from Birunga and Toro-Ankole regions, East and Lentral Equatorial Atrica. 'Ine apparent age of lovo m.y. calculated from the slope of we line corresponas to the age oi ine parental source material.

A granite boay of probably contemporaneous intrusion with the livinamiosumi granite has been reported from the Okinoshima islet, southwestern Sh1koku. SUWA (1967) studied on the granite and concluded that this rock would have been produced by remelting of granulitic or charnokitic basement under the geosynclinal sedimentary rocks. OBA (1962) has discussed on contamination effects of pelitic and basic xenoliths to the Minami-osumi granite, leading a conclusion that the contamination with these xenoliths is responsible for the heterogeneous appearance of the granite. OBA (1966) has also reported the chemical analyses of the granites of the Outer Zone of Southwest Japan and concluded that the chemical nature of the granites would have resulted from the remelting and assimilation of the geosynclinal sedimentary rocks and also older rocks beneath them.

A much older age of 426 m.y. on biotite gneiss and garnet amphibolite has been reported by HAYASE and NOHDA (1969). These rocks are squeezed out in 
the tectonic zone of the Chichibu terrain and associated with Silurian sedimentary formations, as has been reported by MATsumoto and KANMERA (1949), HAMADA (1959) and NoDA (1961).

Whether these older rocks had existed or not in the parental source region before the formation of the Minami-osumi granite is in conjecture, however, the presence of xenoliths of schistose rock in the granite (NOZAWA and OTA, 1967), a sample of which is plotted at a point over the isochron, is the evidence for the existence of older rocks in the source region. Furthermore, the initial strontium $87 / 86$ ratio of the granite is definitely higher than the average ratio of Ocean Ridge tholeiitic basalts (HEDGE et al., 1970; GAST, 1967; TATSUMOTO et al., 1965; FERrara et al., 1969) and/or the average ratio of island basalts from the Pacific Ocean (Powell et al., 1966; Hedge, 1966; Stueber et al., 1966). Therefore it follows that the granite should have originated in the preexisting acid material. Then a primary isochron may have existed, as the variation of rubidium strontium ratios was produced in the granite. Since no information is available for the estimation of the order of an age given by the primary isochron, the whole rock isochron age seems to represent the possible oldest time limit of the differentiation of the granitic magma. The whole rock age of the granites from Amami-oshima also seems to be the oldest limit.

From the above reasoning we tentatively conclude that the Minami-osumi granite was intruded some time in Oligocene or Eocene, that some part of it was eroded and then deposited in the Nichinan group, and that some K-Ar ages on biotites from the granite may represent rejuvenation of the granite, when the mylonite was formed. The whole rock age of the Minami-osumi granite and that of the granites in Amami-oshima may represent the oldest time limit of differentiation of these granitic magma. Relatively high initial ratios of these granite, along with other lines of evidence, are assumed to suggest that considerably older rocks existed in some deeper parts in which the granitic material may have been originated.

\section{References Cited}

BeLL, K. and Poweld, J. L. (1967): Strontium isotopic studies of alkali rocks: the potassium-rich lavas of the Birunga and Toro-Ankole regions, East and Central Equatorial Africa. Jour. Petrol., 10, (3), 536-572.

Brooks, C., WendT, I. and HaRRe, W. (1968): A two-error regression treatment and its application to $\mathrm{Rb}-\mathrm{Sr}$ and initial $\mathrm{Sr}^{87} / \mathrm{Sr}^{88}$ ratios of young granitic rocks from the Schwarzwald Massif, Southwest Germany. Jour. Geophys. Res., 73, (18), 6071-6083.

Ferrara, G., Clarke, W. B., Murthy, V. R. and Bass, M. N. (1969) : K-Ar ages of Juan Fernandez Islands and southeast Pacific dredge hauls (abstract). Amer. Geophys. Union Trans., 50, 329.

GAST, P. W. (1967): Isotope geochemistry of volcanic rocks, 1. In: H. H. HeSS and A. PoldervaArt (editors), Basalt-The PoldervaArt treaties on rocks of basaltic composition, 325-358, New York: Interscience Publishers.

GoraI, M. (1970): Some problems in the mantle origin hypothesis of calc-alkaline magmas. Jour. Geol. Soc. Japan, 76, (11), 529-536 (In Japanese with English abstract). 
HAMADA. T. (1959) : Gotlandian stratigraphy of the Outer Zone of Southwest Japan. Jour. Geol. Soc. Janan. 77. (4). 207-220.

HASHimoтo. J. (1961): Tertiary Molluscan fossils from the Kadogawa formation, Mivazaki Prefecture, Japan. Rep. Earth Sci. Dept. General Education, Kuushu Univ., 7. 69-94.

(1962): The sedimentarv complex of uncertain ages in south Kyushu. ibid., 9. 13-69 (In Japanese with English abstract).

and Miyahisa. M. (1959): Stratioraphical seauence and geological structure of the Tomi-vama Peninsula. Mivazaki Prefecture-Some problems concerning the geologic historv of the Shimanto terrain in Kyushu. ibid.. 6. 29-51 (In Japanese with English abstract).

HATA ${ }^{5}$. N. et al. (1955): Fiplanatorv of the geological map of the Amami Island, Kagoshima Prefecture $(1: 200.000)$. Amami Office, Kagoshima Pref. (In Japanese).

Hayasf, I. and Ishizaka. K. (1968): Rb-Sr dating on the rocks in Tapan (1). Southwestern .Tapan. Jour. Irnan. Assne. Mineral. Petrol. Econ. Geol.. 58. 201-212 (In Jananese with English abstract).

HAYASF. I. and NoHDA. S. (1969): Geochronology on the "Oldest Rocks" of Japan. Geochem. Jour., 3. (1). 45-52.

HFDGF. C. E. (1966): Variations in radiometric strontium found in volcanic rocks. .Jour. Geonhus. Res. 71. 6119-6126. and Pretriman. 7. F. (1970): The strontium isotopic comnosition of basalts from the Gordo and Tuan de Fuca Rises, Northeastern Pacific Ocean. Contr. Mineral. and Petrol.. 27, 114-120.

тмat. T. Thraoka. Y. and Okumura. K. (1971): Fenlogic structure and metamorphic monation of the northern nart of the Shimanto terrain in Kvushu. Japan. Jour. Geol. Soc. Janan. 77. (4). 207-22n (Tn Jananese with English abstract).

TÄGER. E., NJgGt, E. E. and W'NK. F. (1967): Rh-Sr-Altersbestimmungen an Glimmern der Zentralalnen. Boitr. 7. Fenl. Karte d. Schweiz. Liefg BL.

Kawano. M., Takahasht. $K$. and Nozawa. T. (1966): Petrochemistrv of Minamiosumi granite in the Uchinoura area. Kvushr. Japan. Bull. Genl. Surv. Japan, 17. (9), 533-541.

KAWANn. V. and ThDs $\mathrm{V},(1966)$ : K-Ar datino on the ioneons ronks in southwest .Tapan. Inur. Inpan. Asenn. Minernt. Petrol. Econ. Gent.. 56. (5), 191-211 (In Tananese with Enolish ahstract).

KoNisur. K. (1965): Gentectonic framework of the Rvukvir Tslands (Nanshei-shoto). Imir. Fent. Sne. Janmm 71. (810), 127-457 (Tn .Tananese with Finglish abstract).

Kuwano. Y. (1960): A Palenorono Foraminiferal farnule from the Osumi Peninsula. Southern Kvinshr. Tanan. Miscellanenus Ren. of the Research Inst. for Natural Resnurees, 52-53, 136-146.

MATSTMOTOT. T. and KANMיRA. K. (1949): Contrihutions to the tectonic history in the Outer 7one of Southwost .Tanan. Mom. For. Sci.. Kunshu Univ.. ID1. 3. (2). 77-90.

Ishikawa, $H$. and Yamakucht. S. (1966): A Mesozoic Ammonite from Amami-oshima. Trans. Prne. Prlmennt. Son. Jonnn. N. S.. (76), 177-184. nl. 20. and Hipata. M. (1969): A new Ammonite from the Shimantogawa group of Shikoku. Trrns. Proc. Prlaennt. Sne. Jannn. N. S.. (76), 177-184. pl. 20.

MILLRr. J. et al. (1962): Pntassium-A rgon a ops of granitic rocks from the Outer Zone of Kvushu. Japan. Bull. Geol. Surv. Janan. 13. (8). 712-714.

Mryahrsa. M. (1958): Tertiarv acid intrusivos and related metallogenic province in the Outer Zone of Krushu and Shikoku. Janan. Mem. Ehime Univ., Nat. Sci., 3, (1), 145-155 (In Jananese with English abstract).

, Kinoshita. K. and Tomita. T. (1953): Ages of the mineral deposits accompanied by acid igneous rocks of the Outer Zone of Kyushu. Jour. Geol. Soc. Japan, 59, 309 (Abstract in Japanese).

Momor, H. (1958): Radium content of some Tertiary granites in Kyushu. Jour. 
Japan. Assoc. Mineral. Petrol. Econ. Geol., 42, (6), 302-308 (In Japanese with English abstract).

NAYlor, R. S., Steiger, R. H. and WASSERbURG, G. J. (1970): U-Th-Pb and Rb-Sr systematics in $2700 \times 10^{8}$-year old plutons from the southern Wind River Range, Wyoming. Geochim. Cosmochim. Acta, 34, 1133-1159.

NodA, M. (1961) : Geology of the Mikuni-toge district, Oita Prefecture, Japan-with special reference to the Gotlandian deposit. Rep. Earth Sci., Dept. General Education, Kyushu Univ., 7, 1-9 (In Japanese with English abstract).

NozAwA, T. (1968): Radiometric ages of granitic rocks in the Outer Zone of Southwest Japan and its extension; 1968 summary and north-shift hypothesis of igneous activity. Jour. Geol. Soc. Japan, 74, (9), 485-489 (In Japanese with English abstract).

and OTA, R. (1967): Geology of the Uchinoura district. Quadangle Series, Scale 1 : 50,000, Kagoshima (15), (102), Geol. Surv. Japan (In Japanese with English abstract).

OBA, N. (1960): The southern Osumi granite. Miscellaneous Rep. of the Research Inst. for Natural Resources, 52-53, 127-135 (In Japanese with English abstract) . (1962): The contamination-effect on the Osumi granite. ibid., 56-57, 148-152 (In Japanese with English abstract).

(1966): Geological meaning of the granitic rocks in the western district of the Shimanto terrain. Sci. Rep. Kagoshima Univ., 15, 13-24.

Ozard, M. J. and Russell, R. D. (1970) : Discrimination in solid source lead isotope aboundance measurement. Earth Planet. Sci. Letters, 8, 331-336.

Powell, J. L. and Delong, S. E. (1966) : Isotope composition of strontium in volcanic rocks from Oahu. Science, 153, 1239-1242.

Shibata, K. and Nozawa, T. (1966): K-Ar ages of granites from Amami-oshima, Ryukyu Islands. Japan. Bull. Geol. Surv. Japan, 17, (7), 430-435. and (1968a): K-Ar ages of granitic rocks from the Outer Zone of Southwest Japan. Geochem. Jour., 1, 131-137.

and $(1968 \mathrm{~b}): \mathrm{K}$-Ar age of Omine-san acid rocks Kishu, Japan. Bull. Geol. Surv. Japan, 19, 8-10.

and - $(1968 \mathrm{c}): \mathrm{K}-\mathrm{Ar}$ ages of granitic rocks of Ashizuri-misaki, Takatsukiyama and Omogo, Shikoku, Japan. ibid., 19, 11-16.

- and (1968d): K-Ar ages of the Osuzu-yama acid rocks, Kyushu, Japan. ibid., 19, 17-20.

and $(1968 \mathrm{e})$ : K-Ar ages of acid rocks of the Nomo-misaki and Hioki mountains, Kyushu. Japan. ibid., 19, 21-24.

and - (1968f): K-Ar ages of Yakujima granite, Kyushu, Japan. ibid., 19, 25-29.

Shuto, T. (1963) : Geologv of the Nichinan area with special reference to the Takachiho disturbance. Sci. Rep., Fac. Sci., Kunshu Univ., 6, (2), 135-166 (In Japanese with English abstract).

Stueber, A. M. and Murthy. V. R. (1966): Strontium isotope and alkali element abundances in ultra-mafic rocks. Geochim. Cosmochim. Acta, 30, 1243-1259.

SuwA, K. (1967) : Granitic rocks of the Okioshima Islet, southwestern Shikoku. In: Professor Shibata, Hidetaka Memorial volume (the chief editor, Suto, T.), 86-93, Tokyo: Kokusai-insatsu (In Japanese with English abstract).

TAtsumoto, M., Hedge, C. E. and Engel, A. E. J. (1965) : Potassium, rubidium, strontium, thorium, uranium and the ratio of strontuim-87 to strontium-86 in ocean tholeiitic basalt. Science, 150, 886-888.

Yamaguchi, M., YANAgI, T. and Hamamoto, R. (1969): Some technical aspects of the rubidium-strontium geochronology. Mem. Fac. Sci. Kyushu Univ., [D], 19, (3), 437-450.

YANAGi, T. and Yamaguchi, M. (1970): Ages of some Pre-cambrian metamorphic rocks in North China. Mem. Fac. Sci., Kyushu Univ., [D], 20, (2), 177-189. 